\title{
Optical sensing of ph and 02 in the evaluation of bioactive self-healing cement
}

Nielsen, Søren Dollerup; Paegle, leva; Borisov, Sergey M.; Kjeldsen, Kasper Urup; Røy, Hans; Skibsted, Jørgen; Koren, Klaus

\section{Published in:}

ACS Omega

Link to article, DOI:

10.1021/acsomega.9b02541

Publication date:

2019

Document Version

Publisher's PDF, also known as Version of record

Link back to DTU Orbit

Citation (APA):

Nielsen, S. D., Paegle, I., Borisov, S. M., Kjeldsen, K. U., Røy, H., Skibsted, J., \& Koren, K. (2019). Optical sensing of ph and $\mathrm{O}$ in the evaluation of bioactive self-healing cement. ACS Omega, 4(23), 20237-20243. https://doi.org/10.10z1/acsomega.9b02541

\section{General rights}

Copyright and moral rights for the publications made accessible in the public portal are retained by the authors and/or other copyright owners and it is a condition of accessing publications that users recognise and abide by the legal requirements associated with these rights.

- Users may download and print one copy of any publication from the public portal for the purpose of private study or research.

- You may not further distribute the material or use it for any profit-making activity or commercial gain

- You may freely distribute the URL identifying the publication in the public portal 


\title{
Optical Sensing of $\mathrm{pH}$ and $\mathrm{O}_{2}$ in the Evaluation of Bioactive Self- Healing Cement
}

\author{
Søren Dollerup Nielsen, ${ }^{*}, \oplus$ Ieva Paegle, ${ }^{\|}$Sergey M. Borisov, ${ }^{\perp} \odot$ Kasper Urup Kjeldsen, ${ }^{\dagger}$ Hans Røy, ${ }^{\dagger}$ \\ Jørgen Skibsted, ${ }^{\S \odot}$ and Klaus Koren*, \\ ${ }^{\dagger}$ Center for Geomicrobiology, ${ }^{\ddagger}$ Aarhus University Centre for Water Technology, Section for Microbiology, Department of \\ Bioscience, and ${ }^{8}$ Department of Chemistry and Interdisciplinary Nanoscience Center (iNANO), Aarhus University, 8000 Aarhus, \\ Denmark \\ "Department of Civil Engineering, Technical University of Denmark, 2800 Kgs. Lyngby, Denmark \\ ${ }^{\perp}$ Institute of Analytical Chemistry and Food Chemistry, Graz University of Technology, 8010 Graz, Austria \\ Supporting Information
}

ABSTRACT: Leakage from cementitious structures with a retaining function can have devastating environmental consequences. Leaks can originate from cracks within the hardened cementitious material that is supposed to seal the structure off from the surrounding environment. Bioactive self-healing concretes containing bacteria capable of microbially inducing $\mathrm{CaCO}_{3}$ precipitation have been suggested to mitigate the healing of such cracks before leaking occurs. An important parameter determining the biocompatibility of concretes and cements is the $\mathrm{pH}$ environment. Therefore, a novel ratiometric $\mathrm{pH}$ optode imaging system based on an inexpensive single-lens reflex (SLR) camera was used to characterize the $\mathrm{pH}$ of porewater within cracks of submerged hydrated oil and gas well

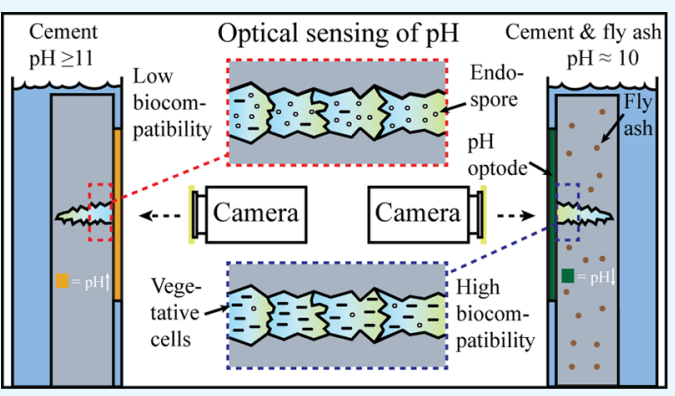
cement. This enabled the imaging of $\mathrm{pH}$ with a spatial distribution in high resolution $(50 \mu \mathrm{m}$ per pixel $)$ and a gradient of $1.4 \mathrm{pH}$ units per $1 \mathrm{~mm}$. The effect of fly ash substitution and hydration time on the $\mathrm{pH}$ of the cement surface was evaluated by this approach. The results show that $\mathrm{pH}$ is significantly reduced from $\mathrm{pH}>11$ to below 10 with increasing fly ash content as well as hydration time. The assessment of bioactivity in the cement was evaluated by introducing superabsorbent polymers with encapsulated Bacillus alkalinitrilicus endospores into the cracks. The bacterial activity was measured using oxygen optodes, which showed the highest bacterial activity with increasing amounts of fly ash substitution in the cement, correlating with the decrease in the $\mathrm{pH}$. Overall, our results demonstrate that the $\mathrm{pH}$ of well cements can be reliably measured and modified to sustain the microbial activity.

\section{INTRODUCTION}

Crack formation can severely reduce the lifetime of cementitious materials. Even small cracks are penetrated by water with erosive and corrosive ions that further widen the cracks and corrode steel reinforcements. ${ }^{1,2}$ In installations designed with a retaining function, cracks may compromise the tightness, allowing either dangerous substances to reach the environment or loss of pressure in a pressurized system. ${ }^{1}$ One such cement application where tightness is highly important is the cementing of wells used in the oil and gas industry. ${ }^{3}$ Here, cementing serves to position steel casings in the borehole and to seal off and isolate different sections of the well. Cracks in oil and gas well cement installations can lead to the loss of zonal isolation in the well, resulting in a significant loss in well productivity with a corresponding negative economic impact. ${ }^{4}$ Another concern is "plug and abandonment" of oil and gas wells, where decommissioned wells are plugged with cement to contain the remnant gas and oil inside the abandoned well. Loss of zonal isolation in active oil and gas wells and fluid leakage due to cracks in cement plugs can lead to serious environmental issues. ${ }^{5}$ Strategies to potentially mitigate these cracks in the cement are self-"healing" or -"sealing" of the cracks by either chemical or biological agents mixed into the wet cementitious mixture. ${ }^{6,7}$ Chemical self-healing agents typically consists of encapsulated precursors of polymers, such as epoxy resins or cyanoacrylates. ${ }^{6,8-10}$ Recently, biologically based healing of concrete has been proposed as an alternative self-healing technique, utilizing bacterial activity to precipitate $\mathrm{CaCO}_{3}$ inside the cracks of concrete in aboveground structures. ${ }^{7,11-14}$ Products of chemical healing agents designed for well cement are commercially available; ${ }^{15,16}$ however, a bioactive self-healing well cement is yet to be engineered. The limitation on biological activity in well cement lies in the nature of the cement composition. Contrary to concretes, well cement does not contain sand or other large aggregates; instead, it is a pure cement paste with various

Received: August 8, 2019

Accepted: October 31, 2019

Published: November 18, 2019 


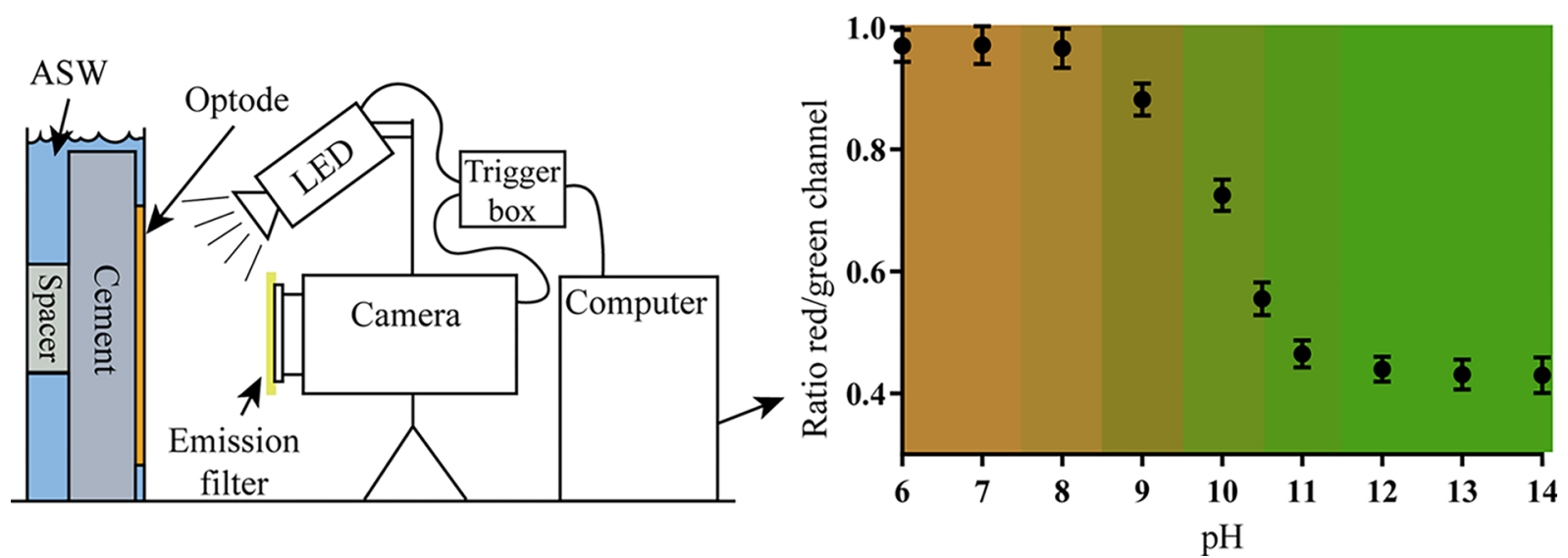

Figure 1. Calibration curve of $\mathrm{pH}$ optode and experimental setup. The colors of the calibration curve are the true colors of the raw RGB images at the respective $\mathrm{pH}$. The calibration curve has its dynamic range between $\mathrm{pH} 8$ and 11 , which is thus the $\mathrm{pH}$ range of the optode. The cement specimen is pressed on the optode and kept in place by a distance spacer. The camera with removed NIR filter is coupled to the LED light source through a trigger box controlled by the image acquisition program on the computer.

additives. ${ }^{17}$ Cement produces alkalinity during hydration due to the dissolution of alkali ions and portlandite $\left(\mathrm{Ca}(\mathrm{OH})_{2}\right)$ from the cement phases. As $\mathrm{pH}$ influences the bacterial activity, it is paramount to investigate the $\mathrm{pH}$ within well cements to further the potential development of a bioactive self-healing cement for use in oil and gas wells.

The $\mathrm{pH}$ of concretes has previously been measured with potentiometric $^{18-20}$ or fiber optic sensors, ${ }^{21,22}$ and recently with optical sensing using planar optodes with an advanced lifetime camera, generating high-resolution images that show a detailed spatial distribution of the $\mathrm{pH}^{23-25}$ Based on measurements with potentiometric sensors, the $\mathrm{pH}$ of concrete can be as high as 12.5; however, these values often represent the $\mathrm{pH}$ of milled concrete suspensions in water and not as such the $\mathrm{pH}$ of the porewater within the cementitious matrix. ${ }^{19,20}$ Fiber optic sensors can be cast inside the cementitious matrix and record the $\mathrm{pH}$ over time $\left(\mathrm{pH} 12.6^{22}\right)$; however, this technique does not take the spatial resolution of the matrix into consideration.

The $\mathrm{pH}$ of well cements has previously only been determined for slurry mixes $(\mathrm{pH}>11.8){ }^{26}$ however, no high-resolution data of the spatial distribution of $\mathrm{pH}$ in the porewater or inside cracks exists for hardened well cements used in the oil and gas industry. Microbial life occurs in natural alkaline environments; however, a $\mathrm{pH}$ above 11 is generally not suitable for bacterial activity. ${ }^{27,28}$ Thus, such high $\mathrm{pH}$ values would hardly allow any bacteria-induced precipitation of $\mathrm{CaCO}_{3}$ to occur.

Here, a basic single-lens reflex (SLR) camera was modified to image the $\mathrm{pH}$ and oxygen consumption in a highly alkaline cracked well cement. In an effort to reduce the $\mathrm{pH}$ of well cement specimens, pozzolanic fly ash was added, which reacts with calcium and hydroxyl ions in solutions, reducing the amount of formed portlandite and thereby the $\mathrm{pH}$ at high substitution levels. ${ }^{29,30}$ A novel $\mathrm{pH}$ planar optode was used to measure the $\mathrm{pH}$ of the porewater in the cement matrix and the water in induced cracks in hardened well cements. The experiments were conducted with various amounts of fly ash substitution to evaluate the effect on the $\mathrm{pH}$. The bioactive potential of well cement was evaluated by measuring the oxygen consumption inside the cracks using oxygen planar optodes.

\section{RESULTS AND DISCUSSION}

Two-Dimensional (2D) Determination of $\mathrm{pH}$ Inside of Cracks of Well Cement. It is paramount to understand the abiotic factors affecting the metabolic activity and growth when implementing biology in a nonbiological system. For cementitious materials, the highly alkaline $\mathrm{pH}$ of the pore solution likely represents a key controlling factor. Imaging $\mathrm{pH}$ at highly alkaline conditions found within cement is not trivial and has only recently been demonstrated for concrete surfaces. ${ }^{23-25}$ While those studies used a lifetime-based readout, the present work is the first report of the ratiometric $\mathrm{pH}$ imaging of cement using a single-lens reflex camera that can be acquired easily and without large investments (approximately \$1000). As the applied $\mathrm{pH}$ indicator emits light in the near-infrared (NIR) region of the electromagnetic spectrum, it was necessary to remove the NIR blocking filter from the camera prior to the experiments. ${ }^{31}$ A typical sigmoidal calibration curve was obtained with this equipment, and the $\mathrm{pH}$ indicator system enabled imaging $\mathrm{pH}$ within the range $8-$ 11 (Figure 1). Measuring $\mathrm{pH}$ optically allowed the visualization of the spatial distribution of $\mathrm{pH}$ in the porewater of the cement matrix and in the induced cracks without destructive sampling. The $\mathrm{pH}$ of the well cement was measured in a high resolution of up to $50 \mu \mathrm{m}$ per pixel with a steep gradient of 1.4 $\mathrm{pH}$ unit per $1 \mathrm{~mm}$ visually observed, equivalent to more expensive systems. ${ }^{23-25}$

The optode design allowed measurements of $\mathrm{pH}$ at the cement surface when pressed against the $\mathrm{pH}$-sensitive film of the optode (Figure 2). The measured values represent the $\mathrm{pH}$ of the water layer in contact with the optode and in direct equilibrium with the porewater in the outer layers of the cement specimens. In agreement, the substitution of fly ash caused the $\mathrm{pH}$ measured inside cracks to decrease (Figure 2). Cement hydration results in the formation of a calciumsilicate-hydrate $(\mathrm{C}-\mathrm{S}-\mathrm{H})$ phase and portlandite as the main hydration products, where the solubility of portlandite buffers the $\mathrm{pH}$ of the pore solution. ${ }^{32}$ The reaction of fly ash consumes portlandite and forms $\mathrm{C}-\mathrm{S}-\mathrm{H}$ and calcium aluminate hydrate phases similar to those found in hydrated Portland cement. ${ }^{30}$ Thus, the degree of fly ash reaction depends on the available amount of portlandite and high substitution levels can thereby be used to reduce the $\mathrm{pH}$ of the pore solution in blended cements. The $\mathrm{pH}$ of the porewater in 


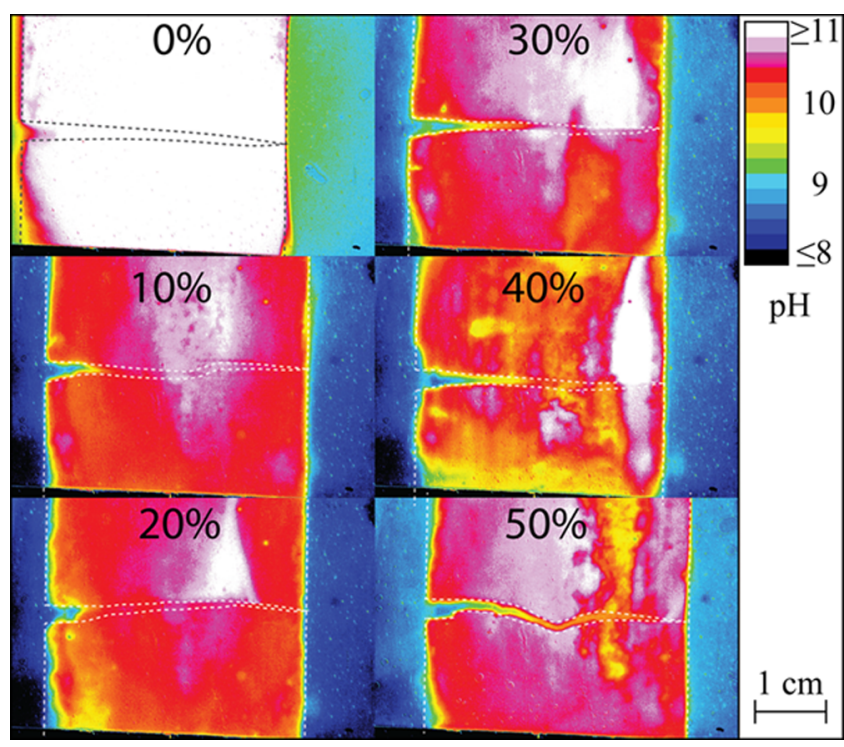

Figure 2. $\mathrm{pH}$ imaging of well cement specimens with varying percentages of fly ash substitution. The optode measures $\mathrm{pH}$ in the range of $8-11$, thus the white color in the images correspond to a $\mathrm{pH}$ value of more or equal to 11 and black less or equal to 8 . The dotted line is the outline of the cement specimens with induced cracks. Substituting 10 wt \% of the cement with fly ash decreases the $\mathrm{pH}$ within the $\mathrm{pH}$ range of the optode. Increasing the substitution of fly ash does not seem to influence the $\mathrm{pH}$ of the porewater in the cement itself; however, the induced crack becomes more and more visible due to a decrease in the cements alkaline buffering capacity. At 30-50 wt $\%$ fly ash substitution, the $\mathrm{pH}$ of the ingressed ASW is not nearly as affected by the cement as in $0-20 \mathrm{wt} \%$. The $40 \mathrm{wt} \%$ specimen had a rougher surface and therefore not as good a contact to the optode as the others, which is why the $\mathrm{pH}$ fluctuates in this particular image. The measurements were highly replicable but did depend on a good specimen to optode contact.

pure well cement hydrated for 1 month exceeded 11 (Figure 2 ), which will expectedly diminish the bacterial activity. ${ }^{27,28}$ The induced crack with the ingress of artificial seawater (ASW, $\mathrm{pH} 8$ ) was equilibrated to the same $\mathrm{pH}$ as the cement porewater within $1 \mathrm{~h}$ of experiment time (Figure 2), suggesting that pure well cement is not compatible with biological healing agents. Notably, the $\mathrm{pH}$ of the pure well cement porewater is above the dynamic $\mathrm{pH}$ range of the optode (Figure 1 and Figure 2). However, other optode chemistries may cover higher $\mathrm{pH}$ values. ${ }^{23,24}$ When substituting the cement by $10 \mathrm{wt}$ $\%$ of fly ash, the $\mathrm{pH}$ of the porewater decreases to a measurable level at $\sim 10.5$. At this $\mathrm{pH}$, for example, Bacillus alkalinitrilicus, which is the biological agent used in self-healing concrete applications, ${ }^{7}$ would still be active but not exhibit growth. ${ }^{33}$ Only the initial wide opening of the crack can be visually seen in the $\mathrm{pH}$ profiles of the $10-20 \mathrm{wt} \%$ fly ash substituted specimens, since the rest of the crack reaches the same $\mathrm{pH}$ as the cement. Apparently, the buffering capacity of portlandite in the blended cement with $10-20 \%$ fly ash substitution was sufficient to increase the $\mathrm{pH}$ of the entering ASW to the level of the cement pore solution. For the 30-40 wt \% fly ash substitution specimens, approximately half of the crack length has a lower $\mathrm{pH}$ than the cement porewater (Figure 2). When $50 \mathrm{wt} \%$ of the cement is replaced by fly ash, the entire crack is visible as the portlandite buffering capacity is reduced to such an extent that the $\mathrm{pH}$ inside the cracks is $\sim 9-10$, which represents the optimum $\mathrm{pH}$ for the growth of $B$. alkalinitrilicus. $^{33}$

Decrease of $\mathrm{pH}$ by Increased Hydration Time to Potentially Sustain Bacterial Activity in Cracks of Well Cement. Portlandite is mainly produced by the reaction of the calcium silicate phases, alite and belite (impure forms of $\mathrm{Ca}_{3} \mathrm{SiO}_{5}$ and $\mathrm{Ca}_{2} \mathrm{SiO}_{4}$, respectively), the principal phases in Portland cement, which also result in the formation of the C$\mathrm{S}-\mathrm{H}$ phase, which is the main phase responsible for the strength development. Alite reacts within hours to days, whereas belite hydration takes place over roughly $1-4$ weeks, contributing to the strength development at later ages. ${ }^{32}$ After a few days, the formed $\mathrm{C}-\mathrm{S}-\mathrm{H}$ phase resulted in a dense material, slowing down the hydration of the remains of alite and belite, as the dissolution and precipitation reactions become diffusion controlled. Fly ash reacts after the hydration of alite and over longer time and thus the amount of portlandite in the cement matrix will decrease with time and increasing degree of fly ash reaction. Thus, the $\mathrm{pH}$ in the pore solution will decrease, in particular after the depletion of portlandite. The consumption of portlandite can explain the decrease in the $\mathrm{pH}$ when comparing cement specimens prehydrated for 1 month $(\mathrm{pH}>11)$ to those prehydrated for 2 months $(\mathrm{pH} \sim 10)$ (Figure 3 ). For the specimen with 50

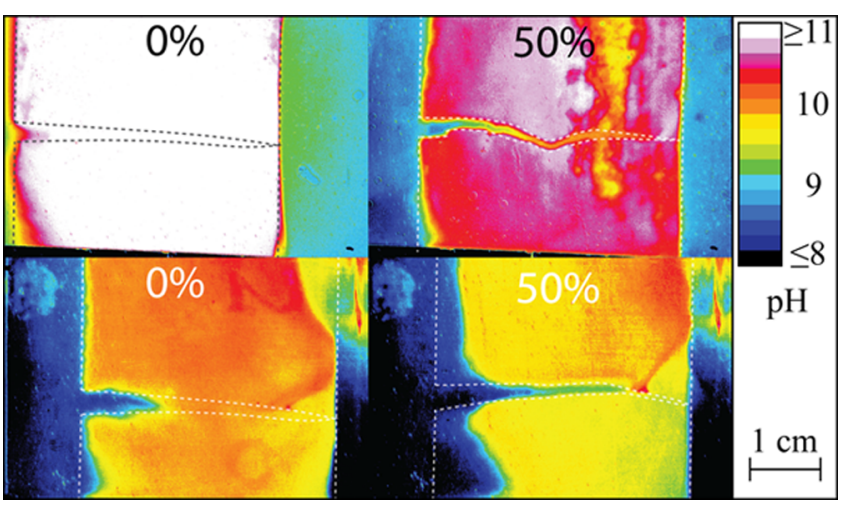

Figure 3. $\mathrm{pH}$ imaging of well cement with 0 or 50 wt \% fly ash substitution and 1 (top) or 2 (bottom) months of prehydration times. Extended prehydration time alone reduces the $\mathrm{pH}$ of the cement porewater from above 11 to $\sim 10$. Substituting $50 \mathrm{wt} \%$ of the cement with fly ash and extending the prehydration time decreased the $\mathrm{pH}$ of the cement porewater to below 10 and that inside the crack to $\sim 9$.

wt \% fly ash substitution, the $\mathrm{pH}$ decreased from 10.5 to 9.75 for the specimens hydrated for 1 and 2 months. The $\mathrm{pH}$ inside the crack decreased even more from 10 to 9.25 in the part of the crack furthest away from the penetrating ASW. Thus, the addition of a significant amount of pozzolanic material such as fly ash to the cement results in an accelerated decrease in $\mathrm{pH}$, thereby potentially further facilitating bacterial activity.

Mapping Bacterial Activity in Well Cement. As discussed above, the measured $\mathrm{pH}$ regime within submillimeter-sized cracks of pure and fly ash substituted well cement suggest that only the fly ash substituted cement specimens will sustain bacterial activity. To test this prediction, freeze-dried superabsorbent polymers (SAPs) with B. alkalinitrilicus endospores were added to cracks in cement specimens and hydrated with a suitable growth medium. The aerobic respiratory activity of the bacteria inside the cracks was subsequently monitored with oxygen optodes, which enables the reversible visualization of oxygen concentrations in $2 \mathrm{D}$ (similarly to the 
$\mathrm{pH}$ optode images) to quantify bacterial oxygen consumption inside the cracks.

In all cement specimens, the oxygen air saturation within cracks containing hydrated SAPs decreased immediately upon exposure to the oxygen optode (Figure 4), demonstrating that

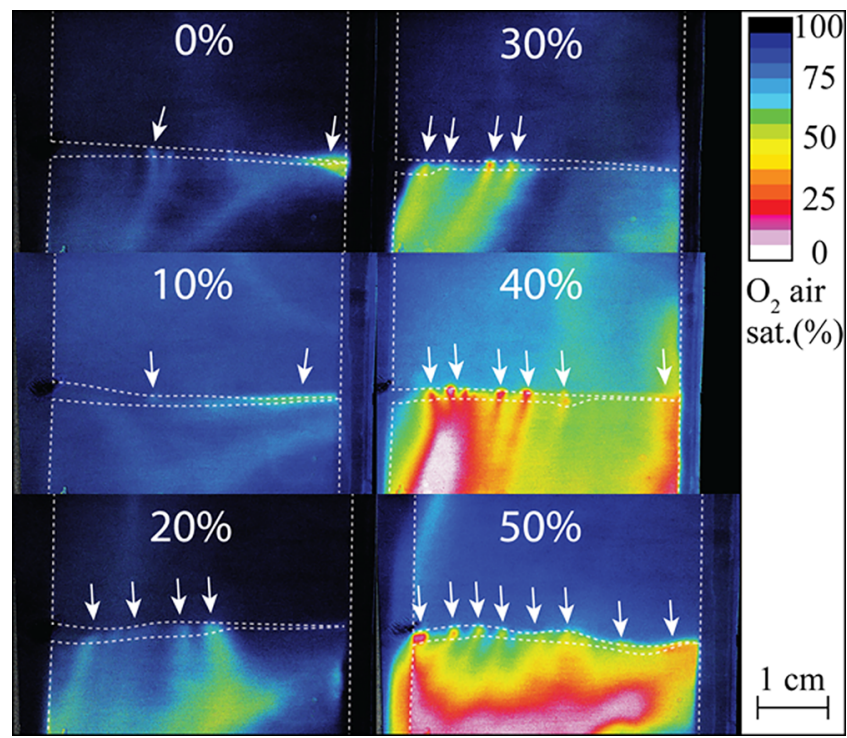

Figure 4. Oxygen imaging of the bacterial activity of SAPs encapsulated endospores induced to germinated inside cracks of well cement. The air saturation decreases due to aerobe bacterial activity. Arrows indicate microbially active SAP particles inside the cracks of the cement specimens. The microbial oxygen consumption is detected in all images, even inside the cracks of pure well cement; however, the activity increases with increasing amounts of fly ash substitution. The oxygen consumption seen in the bottom of the images in the specimens is due to the bacterial activity originating from the crack transported downward by a thin flow of water between the cement specimen and optode.

the embedded endospores of the bacteria were able to germinate and grow even in the pure well cement. However, the inferred respiratory activity was very low and spotty in the cracks of pure well cement but increased substantially with the increasing degree of fly ash substitution and thus decreasing $\mathrm{pH}$ (Figure 2). The $\mathrm{pH}$ decreased from above 10 to 9.25 inside the cracks in these samples with increasing fly ash substitutions. B. alkalinitrilicus has a $\mathrm{pH}$ range of 7-10.2 with an optimum at $9,{ }^{33}$ which leads to more activity and $\mathrm{O}_{2}$ consumption in the samples with the most fly ash substitution, as the $\mathrm{pH}$ inside the cracks in these specimens resembles the $\mathrm{pH}$ optimum of the bacteria. Given that all other parameters, except fly ash substitution, were kept constant, this also highlights $\mathrm{pH}$ as a key factor limiting the bacterial activity in these experiments. In pure well cement, leaching of portlandite due to longer hydration times alone may therefore likely allow bacteria with a $\mathrm{pH}$ tolerance similar to that of $B$. alkalinitrilicus to metabolize and precipitate $\mathrm{CaCO}_{3}$.

The oxygen consumption originates from $B$. alkalinitrilicus loaded SAP particles placed inside the cement cracks in all the cement specimens (Figure 4, arrows). The aerobic $B$. alkalinitrilicus cells use oxygen to oxidize the supplemented electron donor (Na-lactate), and the decrease in oxygen concentration around cracks is due to their activity. In the $2 \mathrm{D}$ images of the oxygen concentration inside cracks (Figure 4), downward streaks of lower oxygen concentrations from the crack opening are evident. These are caused by a flow of a thin watery film between the cement specimen and optode (Figure 4). Unfortunately, surface roughness makes it impossible to avoid such flow-induced movements. Contrary to the $\mathrm{pH}$ optode that is composed of a swelling hydrogel, the oxygen optode used in this study is more sensitive to surface roughness. This explains the observed flow-induced water movement. For structurally complex surfaces, optical sensor particles have been shown to be suitable alternatives, enabling oxygen imaging even on complex biological surfaces. ${ }^{34}$ Nevertheless, for the current study, the oxygen optode system used here was sufficient and enabled the estimations of bacterial activity in $2 \mathrm{D}$.

$\mathrm{pH}$ has not previously been measured in cementitious materials for the application of microbial self-healing compatibility. The evidence of bacterial precipitation of $\mathrm{CaCO}_{3}$ in concrete specimens inoculated with $\mathrm{B}$. alkalinitrilicus is strong. Thus, the $\mathrm{pH}$ in ordinary Portland cement based concrete must be within the biocompatible range. ${ }^{7}$ Concrete surfaces exposed to accelerated carbonation or biogenic acid attack show the $\mathrm{pH}$ values, measured optically, in the range of above 12 to below 10 similar to the results presented here. $^{23-25}$ It is therefore not surprising that the alkaliphile $B$. alkalinitrilicus would metabolize in both concrete and hardened well cement specimens.

\section{CONCLUSIONS}

Oil and gas well cements are very alkaline with the $\mathrm{pH}$ above 11 for pure hydrated cements. Here, we found that the buffering capacity can be reduced to an extent where bacterial activity occurs and thrives by the addition of supplementary pozzolanic materials. Although significant amounts of fly ash may hardly be introduced in well cements for other reasons, the present work shows that the partial replacement of cement by pozzolanic materials may reduce the $\mathrm{pH}$ of the cement pore solution to a level at which the bacterial activity can occur. Thus, this study is a step toward the design of suitable bioactive self-healing well cement formulations that may contribute to a more sustainable construction of future oil wells with longer service life times and an improved material for well abandonment.

\section{EXPERIMENTAL SECTION}

Cement Specimen Preparation. The main component used for the specimen preparation in this study was a class $G$ cement, commonly used for wells in the oil and gas industry. ${ }^{26,35}$ The mix was prepared with $0.25 \%$ by volume of polypropylene fibers to keep the specimens attached after the introduction of cracks, and with varying additions of fly ash (Table 1). The ingredients were mixed by a blender-type homogenizer for $1 \mathrm{~min}$ and then poured into $40 \mathrm{~mm} \times 40 \mathrm{~mm}$

Table 1. Composition of Cement (C), Fly Ash (FA), and Water (W) Fraction by Weight in the Analyzed Specimens

$\begin{array}{ccccccc}\text { sample ID } & 0 \% & 10 \% & 20 \% & 30 \% & 40 \% & 50 \% \\ \text { C:FA:W } & 1: 0: 0.45 & 0.9: 0.1: 0.45 & 0.8: 0.2: 0.45 & 0.7: 0.3: 0.45 & 0.6: 0.4: 0.45 & 0.5: 0.5: 0.45\end{array}$




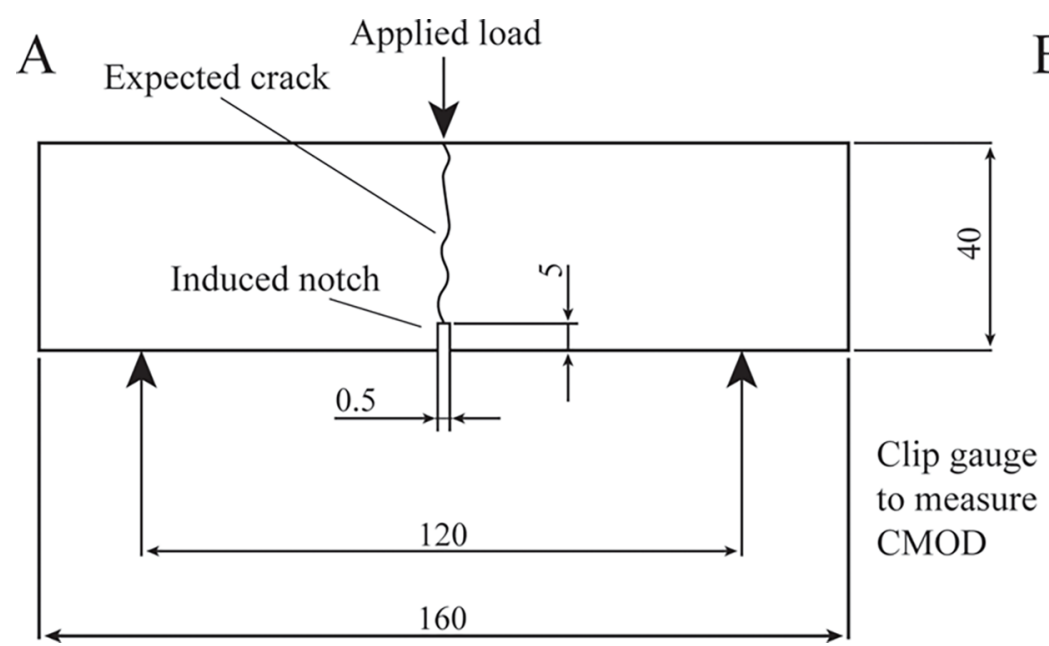

B

Figure 5. Schematic presentation of prismatic cement specimens: (A) specimens geometry $(\mathrm{mm})$ and (B) setup with measuring device capable of inducing cracks in prismatic specimens while continuously measuring the crack width.

$\times 160 \mathrm{~mm}$ prismatic molds. The specimens were demolded after $48 \mathrm{~h}$ and then postcured in demineralized water at $20^{\circ} \mathrm{C}$ for 20 days.

After 20 days of curing, cracks were induced in a 3-point bending setup (Figure 5). The cracks were induced by deformation controlled tests by applying a loading rate of 0.1 $\mathrm{mm} / \mathrm{min}$ of cross-head displacement. When a crack mouth opening displacement (CMOD) of $0.8 \mathrm{~mm}$ was reached, a plastic wedge was installed at the widest part of the crack to keep this size. After cracking, specimens were submerged in demineralized water at $20^{\circ} \mathrm{C}$ for an additional 30 or 60 days to induce portlandite leaching and reduction in $\mathrm{pH}$ before conducting the $\mathrm{pH}$ measurements.

Preparation of $\mathrm{pH}$ and Oxygen Planar Optodes. Luminescence-based $\mathrm{pH}$ and oxygen imaging was performed using planar optodes. For the oxygen-sensitive foil, $1.5 \mathrm{mg}$ of the indicator dye platinum(II) meso-tetra(pentafluorophenyl)porphyrin (PtTFPP; Frontier Scientific, Logan, Utah), $1.5 \mathrm{mg}$ of the reference dye Macrolex fluorescence yellow (Lanxess, Köln, Germany), $100 \mathrm{mg}$ of diamond powder $(1-2 \mu \mathrm{m}$, Microdiamant.com), and $100 \mathrm{mg}$ of polystyrene (MW $\sim 192.000$, Sigma-Aldrich, Taufkirchen, Germany) were dissolved/dispersed in $1 \mathrm{~g}$ of chloroform and knife-coated $(\sim 12 \mu \mathrm{m}$ thickness) on a dust-free poly(ethylene terephthalate) (PET) foil (Puetz Folien, Taunusstein, Germany). The indicator emits in the red part of the spectrum (red channel within a RGB image), while the reference dye emits a green light (green channel).

The $\mathrm{pH}$-sensitive optode consisted of a NIR $\mathrm{pH}$ indicator with a high $\mathrm{p} K_{\mathrm{a}}$, namely, DiF-OH-aza-BODIPY (compound 4 in ref 31), and the green emitting coumarin based reference dye Bu3Coum. ${ }^{36}$ A $0.5 \mathrm{mg}$ of the indicator, $0.4 \mathrm{mg}$ of the reference dye, $100 \mathrm{mg}$ of diamond powder, and $100 \mathrm{mg}$ of Hydromed D4 (purchased from AdvanSource Biomaterials) were dissolved/dispersed in $1 \mathrm{~g}$ of tetrahydrofuran (THF) and again knife coated on a poly(ethylene terephthalate) (PET) foil to give a $\sim 12 \mu \mathrm{m}$ thickness sensor layer.

Optical Sensing of $\mathrm{pH}$ and $\mathrm{O}_{2}$ in Well Cement. The $\mathrm{pH}$ and $\mathrm{O}_{2}$ planar optodes were mounted at the sidewall of a $6 \mathrm{~L}$ aquarium with an electrical tape (carefully avoiding the formation of air bubbles between the glass and the optode). Cement specimens were pressed against the optode with a specially designed distance spacer made of rubber to ensure that the specimen was pressed against the optode as tight as possible (Figure 1). The aquarium was filled with sterile artificial seawater (ASW, void of sulfates to eliminate sulfate attack, salinity of $35 \% \mathrm{o}, \mathrm{pH} 8)$ and kept at $30{ }^{\circ} \mathrm{C}$ using a temperature-controlled Lauda $\alpha$ RA8 water bath (LAUDABrinkmann, LP, Delran, New Jersey). Both optodes were excited using the same blue $(470 \mathrm{~nm})$ LED (i-led, ILH-GD01DEBL-SC201; r-s components, Copenhagen, Denmark) powered by a USB-controlled LED driver unit. ${ }^{37}$ Images were taken after $60 \mathrm{~min}$ of contact with an SLR camera (EOS 1300D; Canon, Tokyo, Japan), modified by removing the nearinfrared filter (NIR filter) to obtain sufficient signal from the $\mathrm{pH}$ indicator. The camera was equipped with a macro objective (100 mm f/2.8 AT-X M100 AF Pro D; Tokina, Tokyo, Japan) and a $530 \mathrm{~nm}$ long-pass filter (OG530 SCHOTT, $52 \mathrm{~mm} \times 2$ $\mathrm{mm})$ to block out the excitation light. LED excitation and image acquisition were controlled and synchronized with the software look@RGB. ${ }^{37}$ The optodes were calibrated in the aquarium in the same ASW prior to the experiment. Oxygen calibrations were obtained by flushing the water in the aquarium with a known air/ $\mathrm{N}_{2}$ mixture (using red-y massflow controllers from Vögtlin, Switzerland), while the oxygen saturation in the aquarium was checked using a calibrated commercial oxygen sensor (OXROB3 oxygen sensor connected to a FireStingGO2; both from Pyroscience, Aachen, Germany) (Figure S1). In a similar fashion, the $\mathrm{pH}$ optode was calibrated by adjusting the $\mathrm{pH}$ within the aquarium adding appropriate amounts of $5 \mathrm{M} \mathrm{NaOH}$ and performing simultaneous reference measurements using a calibrated glass $\mathrm{pH}$ electrode (Radiometer Analytical-Hach Company, Loveland, Colorado) (Figure 1).

Image processing was performed with Image ${ }^{38}$ using the plugin Ratio Plus as described in detail elsewhere. ${ }^{39,40}$

Microbial Activity in Cement Cracks. To assess the potential for sustaining bacterial activity inside cracks of well cement, endospores of $B$. alkalinitrilicus were encapsulated in a superabsorbent polymer (SAP) and manually introduced into cracks. B. alkalinitrilicus endospores were produced on modified Schaeffer's medium and encapsulated in an acrylamide polymer cross-linked with bis-acrylamide to give superabsorbent properties. ${ }^{41}$ The endospore amended SAPs were freeze-dried until all water had sublimated and ground to $<0.5 \mathrm{~mm}$ diameter particles in an agate mortar. The SAP 
particles were placed inside the entire length of the cracks of the well cement specimens with sterile tweezers. The cement specimens with 0-50 wt \% fly ash substitution were prepared identically to the specimens above and prehydrated for 60 days at $20{ }^{\circ} \mathrm{C}$ before the endospore-amended SAPs were added to the cracks. The SAPs were hydrated inside the cracks with a concentrated sodium lactate based medium, Na-lactate 70 $\mathrm{mM}, \mathrm{NaCl} 0.1 \mathrm{M}$, yeast extract (Sigma-Aldrich, St. Louis, Missouri) $1 \mathrm{~g} / \mathrm{L}$, which caused the SAP particles to swell and fill out the entire void of the crack. The specimens were then incubated in a closed humidified plastic container $(0.5 \mathrm{~m} \times 0.3$ $\mathrm{m} \times 0.3 \mathrm{~m}$ ) for 5 days. Every $24 \mathrm{~h}, 2 \mathrm{~mL}$ of sterile medium was added to the cement cracks to support the germination and growth of endospores to a substantial cell density before oxygen measurements by planer optodes in the aquarium setup described above (Figures 1, S1, and S2).

\section{ASSOCIATED CONTENT}

\section{(S Supporting Information}

The Supporting Information is available free of charge on the ACS Publications website at DOI: 10.1021/acsomega.9b02541.

Calibration curve of the oxygen-sensitive planar optode; Microscopy images of the germination and growth of endospore-forming bacteria (Figures S1 and S2) (PDF)

\section{AUTHOR INFORMATION}

\section{Corresponding Authors}

*E-mail: soren.dollerup@bios.au.dk (S.D.N.).

*E-mail: klaus.koren@bios.au.dk (K.K.).

\section{ORCID}

Søren Dollerup Nielsen: 0000-0002-9803-7682

Sergey M. Borisov: 0000-0001-9318-8273

Jørgen Skibsted: 0000-0003-1534-4466

\section{Notes}

The authors declare no competing financial interest.

\section{ACKNOWLEDGMENTS}

We wish to thank Lars B. Pedersen for excellent technical assistance and André Pellerin, Caroline Scholze and Frederik C.R. Thomsen for insightful discussions. This work was funded by the Danish Hydrocarbon Research and Technology Centre (DHRTC) through the Self-Healing Cement project. K.K. would like to acknowledge funding by the Poul Due Jensen Foundation.

\section{REFERENCES}

(1) Schlangen, E.; Joseph, C. Self-Healing Processes in Concrete. In Self-Healing Materials: Fundamentals, Design Strategies, and Applications, 2009; pp 141-182.

(2) Cabrera, J. G. Deterioration of concrete due to reinforcement steel corrosion. Cem. Concr. Compos. 1996, 18, 47-59.

(3) Bittleston, S. H.; Ferguson, J.; Frigaard, I. A. Mud removal and cement placement during primary cementing of an oil well - Laminar non-Newtonian displacements in an eccentric annular Hele-Shaw cell. J. Eng. Math. 2002, 43, 229-253.

(4) Economides, M. J. Implications of Cementing on Well Performance. In Developments in Petroleum Science, Well Cementing, Chapter 1; Nelson, E. B., Ed.; Elsevier, 1990, Vol. 28; pp 1-1-1-6.

(5) Mainguy, M.; Longuemare, P.; Audibert, A.; Lécolier, E. Analyzing the Risk of Well Plug Failure after Abandonment. Oil Gas Sci. Technol. - Rev. IFP 2007, 62, 311-324.
(6) Dry, C. M. Three designs for the internal release of sealants, adhesives, and waterproofing chemicals into concrete to reduce permeability. Cem. Concr. Res. 2000, 30, 1969-1977.

(7) Wiktor, V.; Jonkers, H. M. Quantification of crack-healing in novel bacteria-based self-healing concrete. Cem. Concr. Compos. 2011, 33, 763-770.

(8) Thao, T. D. P.; Johnson, T. J. S.; Tong, Q. S.; Dai, P. S. Implementation of self-healing in concrete-Proof of concept. IES J., Part A: Civ. Struct. Eng. 2009, 2, 116-125.

(9) Brown, E. N.; Sottos, N. R.; White, S. R. Fracture testing of a self-healing polymer composite. Exp. Mech. 2002, 42, 372-379.

(10) Li, V. C.; Lim, Y. M.; Chan, Y.-W. Feasibility study of a passive smart self-healing cementitious composite. Composites, Part B 1998, 29, 819-827.

(11) Jonkers, H. M. Self Healing Concrete: A Biological Approach. In Self Healing Materials; Springer, 2007; pp 195-204.

(12) Wang, J. Y.; Soens, H.; Verstraete, W.; De Belie, N. Self-healing concrete by use of microencapsulated bacterial spores. Cem. Concr. Res. 2014, 56, 139-152.

(13) Wang, J.; Van Tittelboom, K.; De Belie, N.; Verstraete, W. Use of silica gel or polyurethane immobilized bacteria for self-healing concrete. Constr. Build. Mater. 2012, 26, 532-540.

(14) Wang, J. Y.; Snoeck, D.; Van Vlierberghe, S.; Verstraete, W.; De Belie, N. Application of hydrogel encapsulated carbonate precipitating bacteria for approaching a realistic self-healing in concrete. Constr. Build. Mater. 2014, 68, 110-119.

(15) Roy-Delage, L.; Comet, A.; Garnier, A.; Presle, J.-L.; BulteLoyer, H.; Drecq, P. P. A.; Rodriguez, I. U. Self-Healing Cement System-A Step Forward in Reducing Long-Term Environmental Impact. IADC/SPE Drilling Conference and Exhibition; Society of Petroleum Engineers, 2010.

(16) Ravi, K.; Hunter, B.; Kulakofsky, D. In Job Design and Cement System to Contain Steam and Improve Heavy Oil Recovery. World Heavy Oil Congress, 2008; pp 526-533.

(17) Nelson, E. B.; Baret, J.-F.; Michaux, M. 3 Cement Additives and Mechanisms of Action. In Developments in Petroleum Science; Nelson, E. B., Ed.; Elsevier, 1990, Vol. 28; pp 3-1-3-37.

(18) Mansfeld, F.; Shih, H.; Postyn, A.; Devinny, J.; Islander, R.; Chen, C. L. Corrosion Monitoring and Control in Concrete Sewer Pipes. Corrosion 1991, 47, 369-376.

(19) Räsänen, V.; Penttala, V. The pH measurement of concrete and smoothing mortar using a concrete powder suspension. Cem. Concr. Res. 2004, 34, 813-820.

(20) Qi, G. Z.; Niu, D. T.; Yuan, C. F.; Duan, F. Z. Research on the Variation of $\mathrm{pH}$ Value of the Ordinary Concrete and Fly Ash Concrete in the Carbonation Process. Adv. Mater. Res. 2012, 374377, 1934-1937.

(21) Ghandehari, M.; Vimer, C. S. In situ monitoring of $\mathrm{pH}$ level with fiber optic evanescent field spectroscopy. NDT\&E Int. 2004, 37, 611-616.

(22) Nguyen, T. H.; Venugopala, T.; Chen, S.; Sun, T.; Grattan, K. T. V.; Taylor, S. E.; Basheer, P. A. M.; Long, A. E. Fluorescence based fibre optic $\mathrm{pH}$ sensor for the $\mathrm{pH} 10-13$ range suitable for corrosion monitoring in concrete structures. Sens. Actuators, B 2014, 191, 498507.

(23) Müller, B.; Grengg, C.; Schallert, V.; Sakoparnig, M.; Staudinger, C.; Breininger, J.; Mittermayr, F.; Ungerböck, B.; Borisov, S. M.; Dietzel, M.; Mayr, T. Wide-range optical pH imaging of cementitious materials exposed to chemically corrosive environments. RILEM Tech. Lett. 2018, 3, 39-45.

(24) Grengg, C.; Müller, B.; Staudinger, C.; Mittermayr, F.; Breininger, J.; Ungerböck, B.; Borisov, S. M.; Mayr, T.; Dietzel, M. High-resolution optical $\mathrm{pH}$ imaging of concrete exposed to chemically corrosive environments. Cem. Concr. Res. 2019, 116, 231-237.

(25) Grengg, C.; Mueller, B.; Mittermayr, F.; Mayr, T.; Borisov, S.; Dietzel, M. Optical pH imaging of concrete exposed to chemically corrosive environments. MATEC Web Conf. 2018, 199, No. 02007. 
(26) Won, J.; Lee, D.; Na, K.; Lee, I.-M.; Choi, H. Physical properties of G-class cement for geothermal well cementing in South Korea. Renewable Energy 2015, 80, 123-131.

(27) Grant, W.; Mwatha, W.; Jones, B. Alkaliphiles: ecology, diversity and applications. FEMS Microbiol. Lett. 1990, 75, 255-269.

(28) Sorokin, D. Y. Is there a limit for high-pH life? Int. J. Syst. Evol. Microbiol. 2005, 55, 1405-1406.

(29) Hanehara, S.; Tomosawa, F.; Kobayakawa, M.; Hwang, K. Effects of water/powder ratio, mixing ratio of fly ash, and curing temperature on pozzolanic reaction of fly ash in cement paste. Cem. Concr. Res. 2001, 31, 31-39.

(30) Lothenbach, B.; Scrivener, K.; Hooton, R. Supplementary cementitious materials. Cem. Concr. Res. 2011, 41, 1244-1256.

(31) Staudinger, C.; Breininger, J.; Klimant, I.; Borisov, S. M. Nearinfrared fluorescent aza-BODIPY dyes for sensing and imaging of $\mathrm{pH}$ from the neutral to highly alkaline range. Analyst 2019, 144, 23932402.

(32) Taylor, H. F. Cement Chemistry; Thomas Telford, 1997.

(33) Sorokin, D. Y.; Van Pelt, S.; Tourova, T. P. Utilization of aliphatic nitriles under haloalkaline conditions by Bacillus alkalinitrilicus sp. nov. isolated from soda solonchak soil. FEMS Microbiol. Lett. 2008, 288, 235-240.

(34) Koren, K.; Jakobsen, S. L.; Kühl, M. In-vivo imaging of $\mathrm{O}_{2}$ dynamics on coral surfaces spray-painted with sensor nanoparticles. Sens. Actuators, B 2016, 237, 1095-1101.

(35) Noik, C.; Rivereau, A. In Oilwell Cement Durability. SPE Annual Technical Conference and Exhibition; Society of Petroleum Engineers: Houston, Texas, 1999; p 6.

(36) Moßhammer, M.; Strobl, M.; Kühl, M.; Klimant, I.; Borisov, S. M.; Koren, K. Design and Application of an Optical Sensor for Simultaneous Imaging of $\mathrm{pH}$ and Dissolved $\mathrm{O}_{2}$ with Low Cross-Talk. ACS Sens. 2016, 1, 681-687.

(37) Larsen, M.; Borisov, S. M.; Grunwald, B.; Klimant, I.; Glud, R. $\mathrm{N}$. A simple and inexpensive high resolution color ratiometric planar optode imaging approach: application to oxygen and $\mathrm{pH}$ sensing. Limnol. Oceanogr.: Methods 2011, 9, 348-360.

(38) Schneider, C. A.; Rasband, W. S.; Eliceiri, K. W. NIH Image to ImageJ: 25 years of image analysis. Nat. Methods 2012, 9, 671.

(39) Brodersen, K. E.; Koren, K.; Moßhammer, M.; Ralph, P. J.; Kühl, M.; Santner, J. Seagrass-mediated phosphorus and iron solubilization in tropical sediments. Environ. Sci. Technol. 2017, 51, 14155-14163.

(40) Elgetti Brodersen, K.; Koren, K.; Lichtenberg, M.; Kühl, M. Nanoparticle-based measurements of $\mathrm{pH}$ and $\mathrm{O}_{2}$ dynamics in the rhizosphere of Zostera marina L.: effects of temperature elevation and light-dark transitions. Plant, Cell Environ. 2016, 39, 1619-1630.

(41) Nielsen, S. D.; Koren, K.; Löbmann, K.; Hinge, M.; Scoma, A.; Kjeldsen, K. U.; Røy, H. Constraints on $\mathrm{CaCO}_{3}$ precipitation in superabsorbent polymer by aerobic bacteria, submitted for publication, 2019. 